\title{
Evaluation of the Competitive Potential of the Economic Development of the Country: Theoretical Aspects and Russian Practice
}

\author{
Natalia Victorovna Kuznetsova ${ }^{1}$, Natalia Alexandrovna Vorobeva ${ }^{1} \&$ Anastasia Vladimirovna Koroleva ${ }^{1}$ \\ ${ }^{1}$ Far Eastern Federal University, Vladivostok, Russian Foundation \\ Correspondence: Natalia Victorovna Kuznetsova, Far Eastern Federal University, Suhanova Str., 8, 690950, \\ Vladivostok, Russian Foundation.
}

Received: November 20, 2014 Accepted: March 17, 2015 Online Published: May 22, 2015

doi:10.5539/ass.v11n14p149 URL: http://dx.doi.org/10.5539/ass.v11n14p149

\begin{abstract}
The article presents the methodology of evaluation of the competitive potential of the regions, including the three main stages of research, which has been tested during the analysis of competitiveness of Russian regions. During each stage it is calculated the main indexes, and the Integral Index of regional competitiveness, which provide the opportunity to present a complex view of competitive advantages of the regions of the country. As the result of this research it was presented the whole calculation of the development of Russian regions on the basis of competitive ability (2010, 2012 years). Based on the calculations it was identified the main problems of Russian regional industrial development - the obsolescence of the capital assets, insufficient level of investments, the low level of innovation activity of enterprises, etc. The obvious way for solving these problems is the governmental planning system of industrial development (industrial policy). During this research it became obvious that presented methodology allows making a comprehensive analysis of the competitiveness of the regions of the country.
\end{abstract}

Keywords: competitive potential of the economy, competitiveness of the region, Integral Index of regional competitiveness, methodology of the economic development's evaluation, planning of the economy

\section{Introduction}

Nowadays, in conditions of globalization and integration of world economy, the role of governmental policy in the development process of the competitive advantages in the global arena increased.

The problem of improving the competitiveness of the economy, including a reflection of this fact in the global rankings, is on the agenda not only in Russian Federation, but also in the other countries worldwide.

The competitiveness of any region should be examined not only in terms of competition between regions, but also in terms of their cooperation. The presence of a new technology, new products, or a new idea in one region is a testament to its competitiveness. At the same time, the great importance is the ability of a region to construct the relationships with other regions of the country and at the international level.

The factors, which ensuring the regional growth of competitiveness, were considered by modern scholars and experts from three points of views: the cluster approach, the creation of innovation system and the progressive development of entrepreneurship.

In accordance with the cluster concept the competitiveness of one region depends on the presence of a cluster of related industries in this region. Definitely, it is a cluster which creates the critical mass which is necessary for competitive success in certain industries. Therefore, one of the tasks in the system of increasing the competitiveness of the regional potential is the estimation of the possibilities of cluster process (Porter \& Ketels, 2009).

The second point of view based on the binding of the regional competitiveness with the presence of the innovation system in the region. The accumulation of knowledge and the creation of institutions, conducive the innovation, increases the vitality of the regions. The third group of factors related to the conditions and rates of development of the entrepreneurship in the country.

All of the above mentioned factors affect the competitiveness of the country. The impact of these factors is a contentious issue of a great number of debates. However, there is even more controversial issue - possible ways of assessing the competitiveness of the country. 


\section{Methods}

Table 1. Summary of indicators for evaluation of the regional competitiveness (Gelvanovsky, 1999; Chainikova, 2008; Greenberg, 2008)

\begin{tabular}{|c|c|}
\hline & Index of current competitiveness of a region (R1) \\
\hline 1 & GDP per capita, rubles \\
\hline 2 & Industrial output per capita, thousand rubles \\
\hline 3 & Investments in fixed capital per capita, thousand rubles \\
\hline 4 & The share of unprofitable organizations, $\%$ (to total amount) \\
\hline 5 & Total unemployment, \% (to the economically active population) \\
\hline 6 & Agricultural production per capita, thousand rubles \\
\hline 7 & Retail trade turnover per capita, rubles \\
\hline \multirow[t]{3}{*}{8} & Cash income per capita, on average per month, thousand rubles \\
\hline & Index of industrial competitiveness of a region (R2) \\
\hline & Extraction of minerals (Section C, Russian National Classifier of Economic Activities, (RNCEA) \\
\hline 1 & Coefficient of localization of industries in the region $\left(K_{\nu}\right)$ \\
\hline 2 & Coefficient of industrial production per capita in the region $\left(K_{d}\right)$ \\
\hline 3 & Depreciation of capital assets of the industry in the region, $\%$ \\
\hline 4 & Cost of new capital assets in the industry, thousand rubles \\
\hline 5 & Cost of capital assets at the end of the year in the industry, thousand rubles \\
\hline 6 & Coefficient of renewal of capital assets, $\%$ \\
\hline \multirow[t]{2}{*}{7} & Number of people employed in the industry of the region, thousand people \\
\hline & Manufacturing industries (Section D, RNCEA) \\
\hline 1 & Coefficient of localization of industries in the region $\left(K_{l}\right)$ \\
\hline 2 & Coefficient of industrial production per capita in the region $\left(K_{d}\right)$ \\
\hline 3 & Depreciation of capital assets of the industry in the region, $\%$ \\
\hline 4 & Cost of new capital assets in the industry, thousand rubles \\
\hline 5 & Cost of capital assets at the end of the year in the industry, thousand rubles \\
\hline 6 & Coefficient of renewal of capital assets, $\%$ \\
\hline \multirow[t]{2}{*}{7} & Number of people employed in the industry of the region, thousand people \\
\hline & Production and distribution of electricity, gas and water resources (Section D, RNCEA) \\
\hline 1 & Coefficient of localization of industries in the region $\left(K_{l}\right)$ \\
\hline 2 & Coefficient of industrial production per capita in the region $\left(K_{d}\right)$ \\
\hline 3 & Depreciation of capital assets of the industry in the region, $\%$ \\
\hline 4 & Cost of new capital assets in the industry, thousand rubles \\
\hline 5 & Cost of capital assets at the end of the year in the industry, thousand rubles \\
\hline 6 & Coefficient of renewal of capital assets, $\%$ \\
\hline \multirow[t]{2}{*}{7} & Number of people employed in the industry of the region, thousand people \\
\hline & Index of infrastructure development and communications (R3) \\
\hline 1 & Density of public railways, $\mathrm{km}$ of railways per 10 thousand square $\mathrm{km}$ of territory \\
\hline 2 & Density of public roads with hard surface, $\mathrm{km}$ of roads per thousand square $\mathrm{km}$ of territory \\
\hline 3 & Number of registered mobile cellular subscribers, thousand people \\
\hline \multirow[t]{2}{*}{4} & Number of Internet users, thousand people \\
\hline & Index of innovative regional development (R4) \\
\hline 1 & Amount of organizations engaged in research and development, units \\
\hline 2 & Number of personnel engaged in research and development, persons \\
\hline 3 & Population, thousand people \\
\hline 4 & Number of postgraduate students, persons \\
\hline 5 & Number of universities students per 10 thousand people of population, persons \\
\hline 6 & Volume of innovative products in the total volume of products, $\%$ \\
\hline \multirow[t]{2}{*}{7} & Number of registered patents, units \\
\hline & Index of foreign economic activities (R5) \\
\hline 1 & Volume of foreign investments per capita, USD \\
\hline 2 & Foreign trade turnover per capita, USD \\
\hline 3 & Export, USD \\
\hline 4 & Import, USD \\
\hline 5 & Balance of foreign trade turnover per capita, USD \\
\hline 6 & Number of companies with foreign capital, units \\
\hline 7 & Volume of production of companies with foreign capital per capita, thousand rubles \\
\hline
\end{tabular}


The methodological basis of the study are also traditional methods specific to the researching objects of the world economy, such as method of multidimensional comparative analysis, based on the specific empirical data for examining the common features of the economic development of the regions; systematic method, which shows the rate of development of the regions as a certain evolving system, highlighting its basic elements.

During the development of reseaching issues were used a combination of mathematical and statistical methods for researching the economic relationships, such as a method of standardization, which uses for comparing two or more heterogeneous totality on some basis, in this case it is constructed the matrix of standardized coefficients; another method - rating of analysis indexes carried out for the construction of the researching groups; and a method for constructing the integral index, by which it can be examined the degree of distributed competitiveness of the regions (leaders regions, outsiders regions).

During our research, we propose to evaluate the competitive potential of economic development of the country based on the methods consists of three main stages. Firstly, we define the indicators required to calculate a number of Indexes (R1 - R5): Index of current competitiveness of a region (R1); Index of industrial competitiveness of a region (R2); Index of infrastructure development and communications (R3); Index of innovative regional development (R4); Index of foreign economic activities (R5). We formed a matrix of initial data for all five indexes (Table 1).

During the calculation of Index of industrial competitiveness of a region (R2) we selected the data from three types of economic activities (Russian National Classifier of Economic Activities (RNCEA): Section C Extraction of minerals; Section D - Manufacturing industries; Section E - Production and distribution of electricity, gas and water resources, which are the most vividly expressed of regional competitive power.

The coefficient of localization of industries in the region $\left(K_{l}\right)$ was calculated separately, in additional calculations.

The coefficient of localization of industries in the region $\left(K_{l}\right)$ consists of a ratio of the share of some industry in the structure of production to the inheritance weight proportion of the same industry in the country. It is calculated on the basis of gross market production, the main industrial funds and the number of industrial production personnel (Formula 1).

$$
\mathrm{Kl}=(\mathrm{Or} \div \mathrm{Pr} \times 100) \div(O c \div P c \times 100)
$$

where, $O_{r}$ - the industry of the region; $O_{c}$ - the industry of the country; $P_{r}-$ the whole amount of industrial production of the region; $P_{c}-$ the whole amount of production of the country.

The coefficient of industrial production per capita of the region $\left(K_{d}\right)$ calculated as a correlation of specific gravity of the regional production in the volume of national production and the population of the region in the population of the country (Formula 2).

$$
\mathrm{Kd}=(\mathrm{Or} \div \mathrm{Oc})+(\mathrm{Hr} \div \mathrm{Hc})
$$

where, $O_{r}$ - the industry of the region; $O_{c}$ - the industry of the country; $H_{r}$ - the population of the region; $H_{c}-$ the population of the country.

During the second stage of this research we calculated above mentioned Indexes (R1-R5) by the method of multidimensional comparative analysis. These indexes represent the combined rating of the region. It is calculated on the basis of the indicators actually achieved by the regions of the country, using the method of multidimensional comparative analysis. In addition, for each indicator it is determined the best value (maximum or minimum), which is taken as one. Further, the indicators for each region compared with the value of the best indicator. Then, all elements of the graph are divided by the maximum element of the model region.

The specific choice of unifying transformation depends on the type of analyzing indicators:

1) If the basis indicator $x$ is associated with the analyzing integral attribute of monotonically increasing dependence (i.e. the greater is the value of $x$, the better is the economical development of the region), the value of the standardized variable $Y$ was calculated by the following formula (Formula 3):

$$
\mathrm{Y}=(\mathrm{X}-\mathrm{Xmin}) /(\mathrm{Xmax}-\mathrm{Xmin})
$$

where, $X_{\min }$ - the lowest (the worst) value of basis indicator; $X_{\max }$ - the highest (the best) value of basis indicator.

2) If the basis indicator $x$ is associated with the analyzing integral attribute of monotonically decreasing dependence (i.e. the greater is the value of $x$, the worse is the economical development of the region), the value of the standardized variable $\mathrm{Y}$ was calculated by the following formula (Formula 4): 


$$
\mathrm{Y}=(\mathrm{Xmax}-\mathrm{X}) /(\mathrm{Xmax}-\mathrm{Xmin})
$$

The rating index $(\mathrm{R})$ is calculated by the following formula of weighted arithmetic mean (Formula 5):

$$
\mathrm{R}=\sum \mathrm{Ki} \mathrm{Xi} / \sum \mathrm{Ki}
$$

The theoretical basis of this research was approved by the practical calculations of Russian economic development.

According to this research, we have five ratings of Indexes (R1-R5) for the regions of Russian Federation in 2010 and 2012 years (Table 2).

During the third stage of this research we calculated Integral Index and grouped the regions depending on competitiveness.

We cannot use here the grouping method, because it based on only one grouping feature which ignores other important features. We took the values in a scale from 0 to 1 , and calculated the Integral Index. It is obvious how the entities distributed according the level of competitiveness (leaders regions, outsiders regions), and it also possible to use the cartographic modeling.

The Integral Index was calculated using the following formula (Formula 6):

$$
I I=\sum \mathrm{w}_{\mathrm{i}} x_{j}
$$

where, $\mathrm{W}$ - weight of indicator $\mathrm{R}$ (in our research it is 5); $\mathrm{X}$ - criteria for private entities, measured in standardized scale from 0 to 1 .

Based on the calculated data we grouped the regions with rating scores. On the basis of the distribution of ratings it is possible to make conclusions about the degree of competitiveness of the country and its regions.

By calculating the Integral Index (2010 and 2012 years) using the grouping method we define the groups of competitive regions. For this we construct the interval variation series and determine the number of groups.

When constructing the interval variation series we should select the optimal number of groups (intervals) and set the length of the interval. The number of groups is chosen for reflecting the diversity of characteristic values in the research.

The number of groups can be calculated using the following formula (Formula 7):

$$
\mathrm{k}=1+3,322 \lg \mathrm{N}
$$

The length of the interval can be identified by formula (Formula 8):

$$
h=\frac{X \max -X \min }{k}
$$

where, $\mathrm{k}$ - the number of groups; $\mathrm{N}$ - the aggregate number of complex (the number of regions).

In our research: $\mathrm{N}=80$ (because we have 80 researching regions); $\mathrm{k}=7$;

$$
\mathrm{h}=0,6892-0,0990 / 7=0,084
$$

\section{Results}

In this research we evaluated the existing competitive potential of the national economy of Russian Federation. The evaluation of the competitiveness of the Russian regions was based on the method which was described above. It consists of three main stages of evaluation. The main indicators and Indexes (R1-R5) of the competitiveness of the Russian regions were calculated on the basis of Formulas $1-8$. During our analysis we

The number of groups is 7 . The scale of variation is 0,084 .

Thus, after calculations we have 7 groups of regions, which formed in terms of indicators of regional competitiveness:

I - developed regions $(0,603$ - and higher $)$

II - temperately-developed regions $(0,519-0,603)$

III - lagging regions $(0,435-0,519)$

IV - temperately-lagging regions $(0,351-0,435)$

$\mathrm{V}-$ limited developing regions $(0,267-0,351)$

$\mathrm{VI}$ - depression regions $(0,183-0,267)$

VII - undeveloped regions $(0,099-0,183)$ 
Table 2. Summary of calculating Indexes (R1-R5) and Integral Index of Russian regions, 2012

\begin{tabular}{|c|c|c|c|c|c|c|}
\hline Regions & R1 & R2 & R3 & R4 & R5 & Integral Index \\
\hline Belgorod Region & 0.524 & 0.223 & 0.472 & 0.116 & 0.090 & 0.285 \\
\hline Bryansk Region & 0.308 & 0.172 & 0.369 & 0.113 & 0.066 & 0.205 \\
\hline Vladimir Region & 0.330 & 0.224 & 0.393 & 0.110 & 0.081 & 0.228 \\
\hline Voronezh Region & 0.419 & 0.216 & 0.407 & 0.168 & 0.084 & 0.259 \\
\hline Ivanovo Region & 0.242 & 0.193 & 0.333 & 0.106 & 0.050 & 0.185 \\
\hline Kaluga Region & 0.402 & 0.266 & 0.407 & 0.083 & 0.176 & 0.267 \\
\hline Kostroma Region & 0.263 & 0.150 & 0.242 & 0.072 & 0.049 & 0.155 \\
\hline Kursk Region & 0.388 & 0.189 & 0.412 & 0.112 & 0.057 & 0.231 \\
\hline Lipetsk Region & 0.426 & 0.251 & 0.433 & 0.096 & 0.095 & 0.260 \\
\hline Moscow Region & 0.420 & 0.400 & 0.910 & 0.276 & 0.224 & 0.446 \\
\hline Orel Region & 0.358 & 0.166 & 0.385 & 0.125 & 0.049 & 0.216 \\
\hline Ryazan Region & 0.375 & 0.187 & 0.328 & 0.106 & 0.052 & 0.210 \\
\hline Smolensk Region & 0.323 & 0.223 & 0.380 & 0.087 & 0.085 & 0.220 \\
\hline Tambov Region & 0.387 & 0.207 & 0.313 & 0.099 & 0.047 & 0.211 \\
\hline Tver Region & 0.294 & 0.285 & 0.356 & 0.096 & 0.066 & 0.219 \\
\hline Tula Region & 0.331 & 0.275 & 0.459 & 0.109 & 0.081 & 0.251 \\
\hline Yaroslavl Region & 0.321 & 0.227 & 0.359 & 0.129 & 0.074 & 0.222 \\
\hline Moscow City & 0.592 & 0.488 & 0.790 & 0.873 & 0.722 & 0.693 \\
\hline Republic of Karelia & 0.261 & 0.189 & 0.254 & 0.067 & 0.065 & 0.167 \\
\hline Komi Republic & 0.476 & 0.229 & 0.208 & 0.095 & 0.083 & 0.218 \\
\hline Arkhangelsk Region & 0.355 & 0.221 & 0.226 & 0.097 & 0.114 & 0.203 \\
\hline Vologda Region & 0.363 & 0.283 & 0.256 & 0.087 & 0.086 & 0.215 \\
\hline Kaliningrad Region & 0.308 & 0.220 & 0.551 & 0.077 & 0.227 & 0.277 \\
\hline Leningrad Region & 0.425 & 0.388 & 0.508 & 0.042 & 0.179 & 0.308 \\
\hline Murmansk Region & 0.355 & 0.180 & 0.286 & 0.065 & 0.062 & 0.190 \\
\hline Novgorod Region & 0.336 & 0.222 & 0.349 & 0.067 & 0.064 & 0.208 \\
\hline Pskov Region & 0.273 & 0.203 & 0.309 & 0.072 & 0.057 & 0.183 \\
\hline St. Petersburg City & 0.449 & 0.361 & 0.448 & 0.429 & 0.239 & 0.385 \\
\hline Republic of Adygeya & 0.334 & 0.147 & 0.308 & 0.104 & 0.053 & 0.189 \\
\hline Republic of Kalmykia & 0.265 & 0.149 & 0.122 & 0.074 & 0.036 & 0.129 \\
\hline Krasnodar Territory & 0.431 & 0.294 & 0.548 & 0.149 & 0.140 & 0.312 \\
\hline Astrakhan Region & 0.307 & 0.196 & 0.255 & 0.089 & 0.055 & 0.180 \\
\hline Volgograd Region & 0.328 & 0.269 & 0.326 & 0.121 & 0.090 & 0.227 \\
\hline Rostov Region & 0.379 & 0.262 & 0.372 & 0.208 & 0.118 & 0.268 \\
\hline Republic of Daghestan & 0.260 & 0.164 & 0.184 & 0.115 & 0.065 & 0.158 \\
\hline Republic of Ingushetia & 0.038 & 0.152 & 0.272 & 0.058 & 0.037 & 0.111 \\
\hline Kabardino-Balkarian Republic & 0.254 & 0.172 & 0.281 & 0.066 & 0.043 & 0.163 \\
\hline Karachayevo-Circassian Republic & 0.276 & 0.202 & 0.155 & 0.071 & 0.040 & 0.149 \\
\hline Republic of North Ossetia - Alania & 0.258 & 0.166 & 0.368 & 0.095 & 0.041 & 0.186 \\
\hline Chechen Republic & 0.100 & 0.202 & 0.250 & 0.067 & 0.047 & 0.133 \\
\hline Stavropol Territory & 0.369 & 0.306 & 0.291 & 0.147 & 0.074 & 0.238 \\
\hline Republic of Bashkortostan & 0.419 & 0.285 & 0.397 & 0.172 & 0.117 & 0.278 \\
\hline Republic of Mari El & 0.307 & 0.157 & 0.214 & 0.073 & 0.050 & 0.160 \\
\hline Republic of Mordovia & 0.340 & 0.205 & 0.288 & 0.159 & 0.046 & 0.208 \\
\hline Republic of Tatarstan & 0.478 & 0.353 & 0.556 & 0.235 & 0.166 & 0.358 \\
\hline Udmurtian Republic & 0.326 & 0.197 & 0.323 & 0.122 & 0.065 & 0.207 \\
\hline Chuvash Republic & 0.290 & 0.193 & 0.389 & 0.162 & 0.051 & 0.217 \\
\hline Perm Territory & 0.412 & 0.310 & 0.259 & 0.142 & 0.099 & 0.244 \\
\hline Kirov Region & 0.305 & 0.188 & 0.233 & 0.101 & 0.059 & 0.177 \\
\hline Nizhny Novgorod Region & 0.376 & 0.326 & 0.462 & 0.216 & 0.103 & 0.297 \\
\hline Orenburg Region & 0.373 & 0.232 & 0.298 & 0.103 & 0.074 & 0.216 \\
\hline Penza Region & 0.303 & 0.190 & 0.339 & 0.126 & 0.055 & 0.203 \\
\hline Samara Region & 0.424 & 0.296 & 0.521 & 0.224 & 0.108 & 0.315 \\
\hline Saratov Region & 0.335 & 0.244 & 0.381 & 0.150 & 0.081 & 0.238 \\
\hline Ulyanovsk Region & 0.313 & 0.226 & 0.321 & 0.128 & 0.056 & 0.209 \\
\hline Kurgan Region & 0.275 & 0.160 & 0.208 & 0.084 & 0.049 & 0.155 \\
\hline Sverdlovsk Region & 0.435 & 0.375 & 0.456 & 0.190 & 0.120 & 0.315 \\
\hline Tyumen Region & 0.744 & 0.572 & 0.368 & 0.143 & 0.295 & 0.424 \\
\hline Chelyabinsk Region & 0.357 & 0.333 & 0.421 & 0.178 & 0.098 & 0.277 \\
\hline Republic of Altai & 0.287 & 0.160 & 0.074 & 0.049 & 0.036 & 0.121 \\
\hline Republic of Buryatia & 0.288 & 0.233 & 0.101 & 0.120 & 0.054 & 0.159 \\
\hline Republic of Tuva & 0.204 & 0.264 & 0.065 & 0.042 & 0.037 & 0.122 \\
\hline Republic of Khakassia & 0.295 & 0.199 & 0.220 & 0.056 & 0.065 & 0.167 \\
\hline Altai Territory & 0.333 & 0.217 & 0.240 & 0.112 & 0.065 & 0.193 \\
\hline Trans-Baikal Territory & 0.266 & 0.205 & 0.092 & 0.120 & 0.061 & 0.149 \\
\hline
\end{tabular}




\begin{tabular}{|c|c|c|c|c|c|c|}
\hline Regions & R1 & $\mathbf{R 2}$ & R3 & R4 & R5 & Integral Index \\
\hline Krasnoyarsk Territory & 0.426 & 0.365 & 0.292 & 0.143 & 0.108 & 0.267 \\
\hline Irkutsk Region & 0.347 & 0.247 & 0.224 & 0.141 & 0.092 & 0.210 \\
\hline Kemerovo Region & 0.331 & 0.279 & 0.342 & 0.092 & 0.110 & 0.231 \\
\hline Novosibirsk Region & 0.358 & 0.221 & 0.397 & 0.204 & 0.095 & 0.255 \\
\hline Omsk Region & 0.367 & 0.247 & 0.266 & 0.142 & 0.073 & 0.219 \\
\hline Tomsk Region & 0.361 & 0.227 & 0.164 & 0.186 & 0.064 & 0.201 \\
\hline Republic of Sakha (Yakutia) & 0.463 & 0.279 & 0.081 & 0.093 & 0.084 & 0.200 \\
\hline Kamchatka Territory & 0.383 & 0.173 & 0.168 & 0.085 & 0.053 & 0.172 \\
\hline Primorye Territory & 0.350 & 0.188 & 0.285 & 0.128 & 0.107 & 0.212 \\
\hline Khabarovsk Territory & 0.386 & 0.280 & 0.207 & 0.151 & 0.065 & 0.218 \\
\hline Amur Region & 0.383 & 0.238 & 0.172 & 0.079 & 0.054 & 0.185 \\
\hline Magadan Region & 0.445 & 0.209 & 0.175 & 0.105 & 0.063 & 0.200 \\
\hline Sakhalin Region & 0.688 & 0.224 & 0.153 & 0.191 & 0.439 & 0.339 \\
\hline Jewish Autonomous Region & 0.288 & 0.151 & 0.140 & 0.074 & 0.040 & 0.139 \\
\hline Chukotka Autonomous Area & 0.596 & 0.212 & 0.058 & 0.003 & 0.064 & 0.187 \\
\hline
\end{tabular}

Retrieved from: (Official Handbook 'Regions of Russia', 2010, 2012, 2013; Official Handbook 'Regions of Russia', 2010; Official Handbook 'Industries of Russia', 2010; The Ministry of economic development of Russian Federation, 2014; Rigby, 2009; Indicators. The World Bank; Econ Stats: Economic Statistics and Indicators by Country and Region; Trade and investment. Central Intelligence agency, 2014)

During this research we identified the groups of development of Russian regions. The distribution of the regions submitted below (Table 3).

Table 3. Distribution of Russian regions according to the results of calculations

\begin{tabular}{|c|c|c|c|}
\hline \multirow[t]{2}{*}{ Groups of regions } & \multirow{2}{*}{$\begin{array}{l}\text { Interval values of the } \\
\text { Integral Index }\end{array}$} & \multicolumn{2}{|c|}{ Regions of Russian Federation } \\
\hline & & 2010 year & 2012 year \\
\hline I - developed regions & $0.603-$ and higher & Moscow City & Moscow City \\
\hline $\begin{array}{l}\text { II - temperately-developed } \\
\text { regions }\end{array}$ & $0.519-0.603$ & - & - \\
\hline III - lagging regions & $0.435-0.519$ & Moscow Region & Moscow Region \\
\hline $\begin{array}{l}\text { IV - temperately-lagging } \\
\text { regions }\end{array}$ & $0.351-0.435$ & $\begin{array}{l}\text { St. Petersburg City } \\
\text { Tyumen Region }\end{array}$ & $\begin{array}{l}\text { St. Petersburg City } \\
\text { Republic of Tatarstan } \\
\text { Tyumen Region }\end{array}$ \\
\hline V - limited developing regions & $0.267-0.351$ & $\begin{array}{l}\text { Krasnodar Territory } \\
\text { Rostov Region } \\
\text { Republic of Bashkortostan } \\
\text { Republic of Tatarstan } \\
\text { Nizhny Novgorod Region } \\
\text { Samara Region } \\
\text { Sverdlovsk Region } \\
\text { Chelyabinsk Region } \\
\text { Sakhalin Region }\end{array}$ & $\begin{array}{l}\text { Belgorod Region } \\
\text { Kaluga Region } \\
\text { Kaliningrad Region } \\
\text { Leningrad Region } \\
\text { Krasnodar Territory } \\
\text { Rostov Region } \\
\text { Republic of Bashkortostan } \\
\text { Nizhny Novgorod Region } \\
\text { Samara Region } \\
\text { Sverdlovsk Region } \\
\text { Chelyabinsk Region } \\
\text { Krasnoyarsk Territory } \\
\text { Sakhalin Region }\end{array}$ \\
\hline $\begin{array}{l}\text { VI - depression } \\
\text { regions }\end{array}$ & $0.183-0.267$ & $\begin{array}{l}\text { Belgorod Region } \\
\text { Bryansk Region } \\
\text { Vladimir Region } \\
\text { Voronezh Region } \\
\text { Kursk Region } \\
\text { Lipetsk Region } \\
\text { Orel Region } \\
\text { Ryazan Region } \\
\text { Smolensk Region } \\
\text { Tambov Region } \\
\text { Tver Region } \\
\text { Tula Region } \\
\text { Yaroslavl Region } \\
\text { Komi Republic } \\
\text { Arkhangelsk Region } \\
\text { Vologda Region } \\
\text { Kaliningrad Region } \\
\text { Leningrad Region } \\
\text { Murmansk Region } \\
\text { Novgorod Region }\end{array}$ & $\begin{array}{l}\text { Bryansk Region } \\
\text { Vladimir Region } \\
\text { Voronezh Region } \\
\text { Ivanovo Region } \\
\text { Kursk Region } \\
\text { Lipetsk Region } \\
\text { Orel Region } \\
\text { Ryazan Region } \\
\text { Smolensk Region } \\
\text { Tambov Region } \\
\text { Tver Region } \\
\text { Tula Region } \\
\text { Yaroslavl Region } \\
\text { Komi Republic } \\
\text { Arkhangelsk Region } \\
\text { Vologda Region } \\
\text { Murmansk Region } \\
\text { Novgorod Region } \\
\text { Republic of Adygeya } \\
\text { Volgograd Region }\end{array}$ \\
\hline
\end{tabular}




\begin{tabular}{|c|c|c|c|}
\hline & & $\begin{array}{l}\text { Astrakhan Region } \\
\text { Volgograd Region } \\
\text { Stavropol Territory } \\
\text { Republic of Mordovia } \\
\text { Udmurtian Republic } \\
\text { Chuvash Republic } \\
\text { Perm Territory } \\
\text { Saratov Region } \\
\text { Ulyanovsk Region } \\
\text { Republic of Khakassia } \\
\text { Altai Territory } \\
\text { Krasnoyarsk Territory } \\
\text { Irkutsk Region } \\
\text { Kemerovo Region } \\
\text { Novosibirsk Region } \\
\text { Omsk Region } \\
\text { Republic of Sakha (Yakutia) } \\
\text { Primorye Territory } \\
\text { Khabarovsk Territory }\end{array}$ & $\begin{array}{l}\text { Republic of North Ossetia - Alania } \\
\text { Stavropol Territory } \\
\text { Republic of Mordovia } \\
\text { Udmurtian Republic } \\
\text { Chuvash Republic } \\
\text { Perm Territory } \\
\text { Orenburg Region } \\
\text { Penza Region } \\
\text { Saratov Region } \\
\text { Ulyanovsk Region } \\
\text { Altai Territory } \\
\text { Irkutsk Region } \\
\text { Kemerovo Region } \\
\text { Novosibirsk Region } \\
\text { Omsk Region } \\
\text { Tomsk Region } \\
\text { Republic of Sakha (Yakutia) } \\
\text { Primorye Territory } \\
\text { Khabarovsk Territory } \\
\text { Amur Region } \\
\text { Magadan Region } \\
\text { Chukotka Autonomous Area }\end{array}$ \\
\hline $\begin{array}{l}\text { VII - undeveloped } \\
\text { regions }\end{array}$ & $0.099-0.183$ & $\begin{array}{l}\text { Ivanovo Region } \\
\text { Kostroma Region } \\
\text { Republic of Karelia } \\
\text { Pskov Region } \\
\text { Republic of Adygeya } \\
\text { Republic of Kalmykia } \\
\text { Republic of Daghestan } \\
\text { Republic of Ingushetia } \\
\text { Kabardino-Balkarian } \\
\text { Republic } \\
\text { Karachayevo-Circassian Republic } \\
\text { Republic of North Ossetia - Alania } \\
\text { Chechen Republic } \\
\text { Republic of Mari El } \\
\text { Kirov Region } \\
\text { Penza Region } \\
\text { Kurgan Region } \\
\text { Republic of Altai } \\
\text { Republic of Buryatia } \\
\text { Republic of Tuva } \\
\text { Trans-Baikal Territory } \\
\text { Tomsk Region } \\
\text { Kamchatka Territory } \\
\text { Amur Region } \\
\text { Magadan Region } \\
\text { Jewish Autonomous Region } \\
\text { Chukotka Autonomous Area } \\
\end{array}$ & $\begin{array}{l}\text { Kostroma Region } \\
\text { Republic of Karelia } \\
\text { Pskov Region } \\
\text { Republic of Kalmykia } \\
\text { Republic of Daghestan } \\
\text { Republic of Ingushetia } \\
\text { Kabardino-Balkarian } \\
\text { Republic } \\
\text { Karachayevo-Circassian } \\
\text { Republic } \\
\text { Chechen Republic } \\
\text { Republic of Mari El } \\
\text { Kirov Region } \\
\text { Kurgan Region } \\
\text { Republic of Altai } \\
\text { Republic of Buryatia } \\
\text { Republic of Tuva } \\
\text { Republic of Khakassia } \\
\text { Trans-Baikal Territory } \\
\text { Kamchatka Territory } \\
\text { Jewish Autonomous Region }\end{array}$ \\
\hline
\end{tabular}

The economic development of Russia in 2001-2012 years was characterized by the increasing trends with the annual rate of $4.7 \%$, but it was extremely irregular. Conditionally, we can distinguish the following three periods.

The first is the period of $2001-2008$ years. It was a period of the economic recovery after the transformational crisis and recovery of fiscal crisis in 1998. The average GDP growth rate during this period was $6.6 \%$, which made it possible by 2006, according the size of the economy, to achieve the level of 1991, and by the end of this period increase this rate over $18 \%$. The favorable external economic environment has resulted in strong positivity in the balance of payments, and gives a good chance to accumulate foreign exchange reserves. The system of government finances has moved from deficit, insolvency, dependence on foreign loans and huge public debt to surplus, significant amount of reserve funds, and achieved a one of the world's lowest level of governmental debt.

The extremely favorable external conditions provided a significant impulse for economic growth. The world economy after the slowdown in 2001 showed a very dynamic development in almost all regions. The high level 
of global liquidity provides the low cost loans, capital flows to emerging markets and rising prices for commodities. The price of oil during this period increased from 23 USD per barrel in 2001 to more than 130 USD per barrel in the middle of 2008. It was a cause of a significant strengthening of the position of payment balance and the Russian budget.

Constantly growing export revenues became a cause of the growth of public finances. The federal budget surplus in the period of 2001-2008 in average was about $4 \%$ of GDP. It became possible to reduce quickly the amount of public debt (143\% of GDP in 1998 to 6.5\% at the end of 2008) and formulate the budget savings. In 2004 it was created the Stabilization Fund of Russia, which was transformed into the National Welfare Fund and the Reserve Fund in late 2007. In 2008, these funds were collectively accounted for about $16 \%$ of GDP.

Such factors, as the high export revenues and the growth of credit availability have successfully transformed into the growth in domestic demand. The average annual growth of investment in the period of 2001-2008 was amounted to more than $12 \%$, which promote to make a modernization of the domestic production. The most rapidly growing production was recorded in the industries of non-tradable sectors (construction, trade, services).

Thus, in the period of 2001-2008 in Russia it was made the impressive progress in almost all areas of social and economic development. At the same time, it was managed to construct a whole functional system of institutions of market economy, including tax and budget legislation, regulation of property (including the intellectual property), corporate, land and labor relations.

The second is the period of 2009 - 2011 years. It was the period of the global crisis and the renewal of the post-crisis economy which was completed by the end of 2011.

During the global economic crisis, Russian economy demonstrated the greatest degree of cyclical feature of the developed countries' economies. By the middle of 2009 GDP decreased by $10.2 \%$ in comparison of the peak which was reached in the middle of 2008, as a result of the decline of the investment demand by more than $20 \%$ and a great reduction of the investment in stocks. Such great change of the economic dynamics confirmed the continuing dependence on the oil prices, which decreased from more than 130 USD per barrel in the middle of 2008 to less than 40 USD per barrel by the end of the year.

The crisis period was characterized as the tightening of monetary conditions, despite of the active policy of the Bank of Russia for the empowerment of the liquidity of banks. It also began to decline the credit process: the total loan portfolio of non-financial enterprises and households decreased by $2.5 \%$ for 2009 (including such part which addressed to the population - by almost $11 \%$ in the absence of changes in non-financial institutions).

During the conditions of the global financial crisis it has almost stopped the access to the financial resources in the foreign markets. Moreover, the investors massively withdraw funds from developing markets. From August 2008 to March 2009 the net outflow of capital from Russia exceeded 200 billion USD. For preserving the stability of the exchanging rates the Bank of Russia spent about 170 billion USD during this period, which helped the banks and enterprises with significant negative foreign exchange position and the citizens to adapt for changes of the exchange rate. The non-government external debt was significantly reduced: from 505 billion USD (October 1, 2008) to 416 billion USD (April 1, 2009). The real exchange rate of ruble has fallen by $11 \%$ for the period of the crisis phase.

The economic recession in Russia stopped by the middle of 2009, the cause of this also include the improving of the situation in the world markets of raw materials and fuel. The growth of oil prices have resumed in the second quarter of 2009, it was also observed the growth of the demand for Russian raw products in the foreign markets.

The period of 2009-2010 can be characterized as a refusal process of acceptance of the pre-crisis fiscal measures and the formation of the federal budget deficit (6\% of GDP in 2009 and 4\% of GDP in 2010) due to the decrease of budget revenues, and the overall increase in costs associated with the implementation of anti-crisis plan. The budget deficit was based on the usage of public savings. During this period, it was spent more than half of all oil and gas funds, it is about $8.3 \%$ of GDP.

By the end of 2011, almost all of the macroeconomic indicators have reached or exceeded the maximum pre-crisis value.

The recovery of high oil prices led to a depletion of the deficit of the federal budget and resume strengthening of the exchange rate of ruble. The credit activity growths and the main causes are refinancing operations of Central Bank. The money supply continued its growth. The private external debt began to grow with improve of the access to the international capital markets. At the same time the ability of external borrowings has been limited by the main companies of petroleum industry. 
During the period of 2009 - 2011 we observed the structural changes in Russian Economy. From the side of demand the share of household consumption increased while it was the reducing of the share of gross fixed capital formation. In the production sphere, the share of services (with domination of government administration, health, education) has increased by reducing the weight of manufacturing industries, as well as trade.

In 2012 Russian economy has moved to a new phase of growth, which has a number of features, such as a slowdown of both investment and consumer demand with the weakness of the external demand.

The one of the key factors in post-crisis growth in 2010 - 2011 was the recovery of the demand for production and commodity stocks. In 2012 it was completely exhausted. At the same time the period of 2012 year was characterized by negative trends in the global economy and unfavorable weather conditions which led to the loss of the part of the harvest and the increasing in food prices. The dynamics of the most economic indicators began to slowdown in the second half of 2012. The growth of industrial production, investment, construction and retail trade slowed significantly, which led to a slowdown in overall economic dynamics to $3.4 \%$ from $4.3 \%$ in 2011 .

One of the new factors of growth in 2012, which provided a relatively strong growth in consumer spending, was the reducing of the acceleration rate of household savings and wages growth, especially in the public sector. The real wage growth accelerated from $2.8 \%$ in 2011 to $8.4 \%$ in 2012 , mainly due to a significant increase of the wages in military sphere and the employees in education and health sectors. The savings rate has decreased from the average amount of $12 \%$ in 2011 to less than $9 \%$ in the second half of 2012. It was largely due to a significant acceleration in crediting to households, the increase of which was in general 39.4\% for the year 2012.

At the same time in 2012 it was the recovery of tightening of monetary policy. In September, the Bank of Russia raised the refinancing rate and interest rates on its operations by 0.25 percentage points, and the rate of M2 growth declined from $22.3 \%$ in 2011 to $11.9 \%$ in 2012 . It predetermined the rapid slowdown in crediting of the non-financial institutions about $12.7 \%$. The increase of the loans cost started to influence on the dynamics of investment in the second half of last year.

Another new factor of 2012 year was a sharp slowdown of the import and the stronger orientation of the domestic demand for national products. The import growth slowed to $3.6 \%$ versus $29-30 \%$ in 2010-2011, despite of the decreasing of the part of import tariffs. This reduction of the import was connected not only with slowdown of the domestic demand from $9.1 \%$ in 2011 to $4.9 \%$ in 2012, but with a significant change in the structure of demand.

Thus, 2012 was generally characterized by the transition to a new, lower economic growth trajectory while maintaining high export revenues and stimulating fiscal policy - factors that can be exhausted in the near future.

\section{Discussion}

The problems of evaluation of the competitive potential of the country are debatable. A lot of Russian and foreign economic researchers argue about the different techniques, elaborated for making a number of research for estimation the competitive advantages of the economic development.

The research of methodological tools assessing the competitiveness of regions shows that the currently elaborating methodology for assessing the competitiveness of regions is still under development.

It is remarkable that the concept of "competitive potential of the region" is complicated. It has a complex structure and controversial interpretation of its substance, and approaches of its estimation. There is no consensus in the interpretation of this concept in the scientific literature. There are various controversial approaches of its definition and evaluation.

Thus, some researchers (Chernaya, 2009; Komarova, 2007; Andreev, 2011) identify the existence of three points of view about this issue. The first one examined the competitive potential of the region on the basis of the factors' approach, the second one - on the basis of the expert method, and the third one - this concept is interpreted as identical socio-economic (economic) potential issue. This potential is formed at the expense of specific potentials of common economic agents on the basis of the synergistic effect and it considered as the most representative point of view. Furthermore, every approach has its own advantages and limitations.

Based on the approach of integration and sustainable development of any region, some researchers (Neimushin, 2009) propose the following interpretation of the concept of competitive potential which include seven particular types of potential: natural resources, human, investment, production, export, innovation and organizational potentials. This structure is determined by logic of the competitive development of the region, which based on the development of competitive potential as a combination of competitive resources and advantages. In this case, natural resources, human and investment potentials are characterized by some advantages, created on the basis of 
availability of the resources and usage of the basic factors of production. Production, export and innovation potentials are determined by the operating from resource-based benefits which ensure the technological advance of the region from the competitors. Organizational capacity determined by strategic competitive advantage as a result of the usage of company's resources.

Scientists, who investigate the strategic competitiveness of the country, have not completed a list of factors that influence the level of regional strategic competitiveness. In our opinion, evaluation of strategic competitiveness of the region is always associated with the prediction of its parameters. It confirms that the competitiveness of the region is a complex integrated category which determine by a great number of factors.

The competitive potential of the region identified as a possibility of the subject of territorial development at the expense of the available set of particular competitive advantage to attract and retain potential "consumers" of the territory. Competitive potential of the region in economic policy is the basis of competitive advantage. The comparison with its competitive advantages in other regions provides us facts for future developing of the competitive advantages.

From the other side, the competitive advantages of the region dependent on the quality of its human resources and the amount of investment in human capital. For improving the competitiveness of the regional society, firstly, it is necessary to improve the level and quality of life in the region, to raise a level of motivation for self-realization in the career of this region. Human development can be considered as a factor for developing the competitive advantages and the competitive potential of regional society.

Nowadays, it is a great number of the model and methodology which evaluate the regional competitiveness and competitive potential.

Russian economist R. A. Fathudinov (2005) elaborated the approach to the separation of the competitiveness of the region - the factual and the strategic competitiveness. However, he believes that the set of strategic competitiveness indicators should be separate from the overall set of the actual indicators of competitiveness, because its purpose is to form long-term competitiveness.

He determined a number of indicators of strategic competitiveness: effectiveness of government institutions; investment attractiveness; innovative activity and reproduction; quality of the competitive environment and competition; competitiveness of education and healthcare.

Based on the analysis of existing models of evaluation of the national and regional competitiveness, we identified the most important of these models.

Model of the International Institute of Management Development (IMD) (International Institute of Management Development. Access on: http://www.imd.org). This model based on the factors of competitiveness (four main factors): economic development, effectiveness of public administration, effectiveness of entrepreneurship, infrastructure). It includes more than 300 indicators, and the majority of it is the evaluations of the experts. In this model we can find the effort to evaluate the effectiveness of government and entrepreneurship. There are a number of disadvantages of this model, such as a great number of subjective assessments and evaluations, which cannot provide a clear understanding of the concrete situation in the region.

Model of Investment consulting company AV (AV Regions Competition Index) (Investment consulting company AV. Access on: http://www.av-group.ru). This model based on the factors of competitiveness (eight main factors): institutional, real, financial, human, natural, informational, technological capital and market. The evaluation based on 100 indicators and questionnaires. We identify a number of original approaches to the evaluation of the institutional and communications potentials. However, there are some disadvantages of this model - a huge number of indicators and factors which reduces the impact of strategically important one.

Model of the Institute for Strategy and Competitiveness Harvard Business School (Institute for Strategy and Competitiveness Harvard Business School. Access on: http://www.isc.hbs.edu). There are some factors of competitiveness (three main factors): institutional environment, market structure and economic policy. The evaluation of this model based on the statistical indicators and surveys of executives. We highlight that this model includes the evaluation of the factors of market structure and economic policy, which is not obvious for many other foreign models. However, the disadvantage of this model is the ignorance of social factors of the regions.

Thus, during the analysis of existing models and methodologies of evaluation of the national and regional competitive potential, we have identified a wide range of contradictory opinions of selected indicators for the comprehensive analysis of the competitiveness. 
During the analysis of the competitive potential of Russian national economy, we explored the researchers of famous Russian and foreign economists. The most important for this analysis are the authors, such as: Gelvanovsky, M. I. (1999); Greenberg, R. (2008); Mau, B. (2003); Minakir, P. A. (2012); Mikheeva N. N. (2008); Smirnitsky, E. K. (1989); Yasin, E., Yakovlev, A. (2004); Krugman, P. R. (1991); Schumpeter, J. (Schumpeter, 1982); Fujita, M., Krugman, P. (1995); Fukuyama, F. (2006), and others.

\section{Conclusion}

During this research it was developed the methodology, allowing to evaluate the competitiveness of the country's regions, including the analysis of many components of competitiveness (the current competitiveness of the region, the competitiveness of the industry in the region, the development of infrastructure and communications, the innovative development of the region, the development of foreign economic activity in the region of the country). Consequently, after calculations we received a vividly expressed view of regional development in the context of competitiveness.

During the calculations it was identified that the majority of Russian regions were grouped into the category of depressed and undeveloped regions. Therefore, we can speak about the negative development of Russian economy, the almost fully shortage of development in the manufacturing industries, the absence of one strategy for planning of the national industrial policy.

Nowadays, when the share of the direct influence of the state is getting smaller, the necessity of its extent becomes evident. It is completely clear in the situation of elimination of the negative impacts of external effects. It includes the redistribution of income in the state budget, and the administrative prohibition of the usage of hazard technologies, etc. The adjustment of the state of the market mechanism can eliminate the negative effects of market forces.

The reserves of increasing the efficiency of the industry on the basis of the usage of extensive factors were exhausted. It is vitally necessary to provide the reorientation of industry on the intensive, which include the necessity of solving the complex of interrelated issues in the legislative, regulatory, financial, economic, educational, and other spheres. The problems which specific to the Russian industries in the late 1990s and the 2000s remain unsolved: the obsolescence of the capital assets, insufficient level of attraction of investments, the low level of innovation activity of enterprises, and other problems.

\section{Acknowledgement}

The results were achieved within the frameworks of the governmental assignment of Russian Ministry of Education and Science in the sphere of scientific research during the researching assignment \# 26.1478.2014/K "The structural transformation of Russian Economy through the integration installation in the industrial markets of Asia-Pacific Region".

\section{References}

Andreev, V. E. (2011). Competitiveness of the region and the methodology of its evaluation. Retrieved January, 2015, from http://otechestvo.yar.ru/melikh/article2.html

Chainikova, L. N. (2008). Methodological and practical aspects of assessing the competitiveness of the region (p. 148). Tambov University.

Chernaya, I. P. (2009). The problems of evaluation of competitive potential of the border regions in the national strategic policy. Management in Russia and Abroad, 1, 40-50.

Econ Stats: Economic Statistics and Indicators by Country and Region. Economy Watch. Retrieved December 12, 2014, from http://www.economywatch.com/economic-statistics/country/

Fathudinov, R. A. (2005). Competitiveness: Russia and World, 1992-2015 (p. 606). Moscow, Economy.

Fujita, M., \& Krugman, P. (1995). When is the economy monocentric? Regional Science and Urban Economics, 25, 505-528. http://dx.doi.org/10.1016/0166-0462(95)02098-F

Fukuyama, F. (2006). Strong State: Governance and World Order in the XXI century (p. 25). Moscow, AST.

Gelvanovsky, M. I. (1999). National competitiveness: concept, factors, indicators. Issues of statistics, 12, 18-24.

Greenberg, R. (2008). Russian structural policy: between the inevitable and unknown. Problems of Economics, 3, 46-57.

Indicators. The World Bank. Retrieved December 12, 2014, from http://data.worldbank.org/indicator/all

Institute for Strategy and Competitiveness Harvard Business School. Retrieved January 20, 2015, from 
http://www.isc.hbs.edu/Pages/default.aspx

International Institute of Management Development (IMD). Retrieved January 20, 2015, from http://www.imd.org

Investment consulting company $A V$ (AV Regions Competition Index). Retrieved January 20, 2015, from http://www.av-group.ru/know/show/RCI_method/

Komarova, M. A. (2007). About the criteria of regional competitiveness. Ways and Mechanisms of providing the competitiveness of Russian regions, 2, 270-283.

Krugman, P. R. (1991). Increasing returns and economic geography. Journal of Political Economy, 99, 483-499. http://dx.doi.org/10.1086/261763

Mau, B. (2003). Economic and Political Results of 2002 and especially in the economic policy. Problems of Economics, 2, 12-15.

Mikheeva, N. N. (2008). Regional proportion of economic growth in Russia. Region: Economics and Sociology, 2, 225-243.

Minakir, P. A. (2012). On the concept of long-term development of the economy macro-region. Far East. Spatial Economics, 1, 7-28. http://dx.doi.org/10.14530/se.2012.1.007-028

Neimushin, V. (2009). Post-industrial illusions and systematic 'neoindustrialization': choice of Russia in the modern stage of development. Economist, 4, 47-52.

Official Handbook. (2010a). Industries of Russia 2010 (p. 381). Rosstat.

Official Handbook. (2010b). Regions of Russia. Socio-economic indicators in 2010 (p. 996). Rosstat.

Official Handbook. (2012). Regions of Russia. Socio-economic indicators 2012 (p. 878). Rosstat.

Official Handbook. (2013). Regions of Russia. The main characteristics of the Russian Federation (p. 645). Rosstat.

Porter, M., \& Ketels, K. (2009). The competitiveness is at the Crossroads: the ways of Russian economic development. Retrieved November 14, 2014, from http://www.csr.ru/news/original 1324.stm

Rigby, D. K. (2009). Innovations in Turbulent Times. Harvard Business Review, 6, 79-86.

Schumpeter, J. (1982). Theory of Economic Development (p. 159). Moscow.

Smirnitsky, E. K. (1989). Economic indicators of the industry: Handbook (3rd ed., p. 335). Economics.

The foreign trade portal of information: Ministry of economic development of Russian Federation. Retrieved December 10, 2014, from http://www.ved.gov.ru/

Trade and investment. Central Intelligence agency. Retrieved December 12, 2014, from http://www.dfat.gov.au/trade/

Yasin, E., \& Yakovlev, A. (2004). Competitiveness and modernization of the Russian economics. Problems of Economics, 7, 30-42.

\section{Copyrights}

Copyright for this article is retained by the author(s), with first publication rights granted to the journal.

This is an open-access article distributed under the terms and conditions of the Creative Commons Attribution license (http://creativecommons.org/licenses/by/3.0/). 